\title{
Influence of Ice Encasement and Ethylene Regulation on Cellular-protection Responses in Annual Bluegrass
}

\author{
Kevin Laskowski and Emily Merewitz \\ Department of Plant, Soil, and Microbial Sciences, Michigan State University, 1066 Bogue Street, \\ East Lansing, MI 48824
}

\begin{abstract}
AdDitional INDEX words. acclimation, ice cover stress, plant growth regulator, Poa annua, putting green, turfgrass
Abstract. Annual bluegrass (Poa annua var. reptans), when grown as a putting green species, is sensitive to winter injury such as ice cover. Inhibiting plant ethylene production could be a way to improve annual bluegrass tolerance of ice encasement. The goals of this study were to determine how winter conditions and ethylene regulatory treatments affect the antioxidant system, fatty acid composition, and apoplastic proteins of annual bluegrass plant tissues. Ethylene-promotive (1-aminocyclopropane-1-carboxylic acid or ethephon) and ethylene inhibition treatments [aminoethoxyvinylglycine (AVG)] were applied to plants in the field during acclimation. Plant plugs were taken and subjected to low temperature $\left(-4^{\circ} \mathrm{C}\right)$ and ice-encasement treatments in growth chamber conditions. Antioxidant activities of ascorbate peroxidase (APX), peroxidase (POD), catalase (CAT), and superoxide dismutase (SOD) were measured along with malondialdehyde content (MDA) and apoplastic protein content in leaf and crown tissue. Saturated and unsaturated fatty acid contents were measured in leaf, crown, and root tissue. Higher unsaturated fatty acids are often associated with greater low-temperature tolerance. Compared with the untreated controls, ethephontreated annual bluegrass had greater MDA contents, lower POD and SOD activity, and greater saturated and decreased unsaturated fatty acids. Ethylene inhibition treatments caused annual bluegrass to have less saturated fatty acid content and greater unsaturated fatty acid content, a greater content of apoplast proteins, and higher CAT activity when compared with the untreated controls. The activity of APX was greater in AVG-treated annual bluegrass than in controls. Ethylene may reduce physiological health overwinter, and inhibitory treatments may promote winter tolerance by promoting antioxidant activity, apoplast proteins, and the content of unsaturated fatty acids in plant tissues.
\end{abstract}

The process of acclimating to winter conditions and overwintering are both important to the survival of perennial plants in temperate areas. Despite appearances that plants are doing nothing during winter dormancy, limited physiological processes such as respiration are still occurring (Ogren, 2000). Those physiological processes need to be altered during acclimation and protected during winter to maintain functionality under harsh winter conditions for spring regrowth. Plants can protect overwintering tissues via several mechanisms including sugar concentration gradients, changes in fatty acid profiles, and antioxidants (Samala et al., 1998). Evaluating how cellular-protection mechanisms may be affected by winter stresses in species sensitive to winter and determining whether management practices can improve cellularprotection mechanisms are important for developing strategies to reduce winter associated damages.

Annual bluegrass (Poa annua var. reptans), when maintained in a perennial growth habit typical in turfgrass management, is an ice-encasement sensitive species. It has been reported to survive an average of $60 \mathrm{~d}$ of ice cover (Beard, 1964; Tompkins et al., 2004; Vargas and Turgeon, 2004), which contrasts to creeping bentgrass (Agrostis stolonifera), which can survive under ice

Received for publication 24 Sept. 2020. Accepted for publication 28 Oct. 2020. Published online 8 January 2021.

We wish to thank the Michigan Turfgrass Foundation, the Ontario Turfgrass Research Foundation, the Canadian Alliance for Turfgrass Research, the U.S. Golf Association, AgBioResearch of Michigan State University, and the National Institute for Agriculture for funding of this project.

E.M. is the corresponding author. E-mail: merewitz@msu.edu.

This is an open access article distributed under the CC BY-NC-ND license (https://creativecommons.org/licenses/by-nc-nd/4.0/). cover for up to $120 \mathrm{~d}$ (Beard, 1964). Annual bluegrass and creeping bentgrass are typically found as pure or mixed stands on golf course putting greens and fairways. Previously, we have found that treatments that inhibit ethylene improved annual bluegrass recovery following low temperature and ice conditions; and ethylene-promotive treatments reduced or had no effect on winter recovery, depending on the duration (Laskowski and Merewitz, 2020). As inhibiting ethylene may be a viable management practice that could be used to protect annual bluegrass or other turfgrass species during winter dormancy, it is important to understand the mechanism associated with improved tolerance. Additionally, how ethylene regulates acclimation and overwintering is still not fully understood.

Ethylene, the plant hormone commonly associated with stress responses and signaling, is primarily understood for plant stresses such as flooding or submergence (Fukao et al., 2006), thigmomorphogenesis (Biro and Jaffe, 1984), and wounding or pathogen responses (Lund et al., 1998). How ethylene plays a role in acclimation and overwintering is less well understood. Ethylene effects on cold or other winter stress tolerances may be based on plant species or environmental conditions because contrasting results have been found in various studies (Munshaw et al., 2010; Shi et al., 2012; Szalai et al., 2000; Yu et al., 2001; Zhao et al., 2014). It is clear ethylene has a major effect on plant acclimation and tolerance of winter conditions, but a better understanding of the physiological mechanisms associated with ethylene regulation is needed.

Perennial plant species contain different organs such as leaves, roots, and crowns that may have different survival or stressprotection mechanisms while acclimating to cold, surviving ice 
encasement, or overwintering. Here, we investigate several physiological responses such as apoplastic protein content, antioxidant enzymes, and fatty acid changes in response to chemical treatment, cold, and ice encasement in these different plant organs. Measuring apoplastic protein concentration can indicate plant cold and freeze tolerance, because more proteins in the apoplast could reduce ice crystal formation, particularly if they have antifreeze properties (Griffith et al., 1992). In barley (Hordeum vulgare), apoplastic proteins and antioxidants were found to play an important role in cold tolerance associated with salicylic acid treatment (Mutlu et al., 2013). Few studies of turfgrass cold or winterkill responses have investigated all three of these organs simultaneously, and little information exists about antioxidant and apoplastic protein content of important turfgrass species, particularly in response to ethylene regulatory treatments.

Although it sounds counterintuitive when first thinking about ice-encasement stress (a stress that can often result in anoxic conditions under the ice), oxidative stress-protective mechanisms can play an important role in plant survival of ice encasement. This is because a plant can experience a dramatic and rapid shift in oxygen concentration following ice melt. This stress is often referred to as post-anoxic aeration or reaeration stress. The lipid peroxidation and other anomalies associated with lipid damage that result from reaeration can differentiate between anoxia tolerant and intolerant species (Blokhina et al., 1999). Plants also respond to post-anoxic reaeration by modulating their antioxidant system to combat reactive oxygen species that can form, such as hydrogen peroxide (Blokhina et al., 2001). Post-anoxic reaeration has largely been studied with simulated anoxic stress using inert gasses or under flooding conditions, which means the interactions of cold temperatures and real ice encasement on antioxidant systems has not been thoroughly investigated.

Another major change that can occur during acclimation to cold is the alteration of cell membrane composition (Shang et al., 2006). Generally, plants more tolerant of winter conditions, including ice encasement, accumulate more unsaturated fatty acids than saturated fatty acids in their membranes (Dalmannsdottir et al., 2001; Heatherington et al., 1987; Shang et al., 2006). Shifts in fatty acid profiles occurred in annual bluegrass plants under different plant growth regulator treatments during the fall acclimation period (Laskowski et al., 2019). Thus, measurement of fatty acid profiles may be a good indicator for the effects of ethylene regulatory treatments on annual bluegrass acclimation and survival of ice stress.

We hypothesized that ethylene inhibition-induced improvements in annual bluegrass recovery from ice stress could be associated with cellular-protection mechanisms such as a promotion or maintenance of antioxidant enzyme activities, increased unsaturated fatty acid contents, and/or accumulations in apoplastic proteins. Therefore, the objectives of this study were to evaluate ethylene-promotive treatments [ethephon (2-chloroethyl phosphonic acid) and aminocyclopropane-1-carboxylic acid (ACC)] and ethylene inhibition treatment [aminoethoxyvinylglycine $(\mathrm{AVG})]$ effects on annual bluegrass responses to winter stresses.

\section{Materials and Methods}

Plant material and experimental treatments. Plant materials used in this study were generated from the same experiment described in Laskowski and Merewitz (2020), which is also where results regarding plant regrowth and other health indicators were presented. All chemical treatments began on 3 Oct. 2016 and on 6 Oct. 2017 and were applied weekly for 6 weeks on the experimental annual bluegrass putting green field at the Hancock Turfgrass Research Center, East Lansing, MI. The turfgrass canopy was maintained at a height of $0.32 \mathrm{~cm}$. The foliar chemical treatments applied to the field included the following: 1) $7.96 \mathrm{~L} \cdot \mathrm{ha}^{-1}$ ethephon (Proxy; Bayer Environmental Science, Research Triangle Park, NC); 2) $5.26 \mathrm{~g} \cdot \mathrm{ha}^{-1}$ ACC (100 $\mu \mathrm{M}$ spray solution) (Sigma-Aldrich, St. Louis, MO); 3) $33.9 \mathrm{~g} \cdot \mathrm{ha}^{-1}$ AVG (AVG1) (ReTain; Valent BioSciences, Libertyville, IL); and 4) $2.915 \mathrm{~g} \cdot \mathrm{ha}^{-1}$ AVG (AVG2) (Sigma-Aldrich). Untreated plots were sprayed with water and were used as the control plots. Turfgrass plants (circular plugs $10.16 \mathrm{~cm}$ in diameter) were taken from the experimental field following acclimation to about -1 to $4{ }^{\circ} \mathrm{C}$ on 11 Nov. 2016 and 25 Nov. 2017. A total of 160 turfgrass plugs (five chemical treatments $\times$ four sampling time points $\times$ four plot replications $\times$ two stress treatments) were used, taken for the experiment each year, with eight turfgrass cores taken from each plot. The plugs were kept outside until planted in plastic pots $(10.16 \mathrm{~cm} \times 15.24 \mathrm{~cm})$ in a sandy loam soil and put in a low-temperature growth chamber. The plants were given a 2 week period to acclimate to growth chamber conditions at $-2{ }^{\circ} \mathrm{C}$ before stress treatment. For the remainder of the experiment and during stress treatment, the growth chamber was maintained at $-4{ }^{\circ} \mathrm{C}$, with a light level of $200 \mu \mathrm{mol} \cdot \mathrm{m}^{-2} \cdot \mathrm{s}^{-1}$, with a 10-h photoperiod. Treatments inside the growth chamber consisted of 1) no ice or 2) ice-encasement treatments. Iceencasement treatment involved misting deionized water over pots to form an ice layer $(1.3 \mathrm{~cm}$ thick), with periodic misting to prevent ice loss. The grass leaves are small and are not damaged directly by thick ice layers. Four randomly selected pots within each treatment were taken out from the low-temperature growth chamber on $0,20,40$, and $80 \mathrm{~d}$ of ice- or no ice-treated plants. On each sampling day, plants were destructively sampled, and samples were manually split into leaves, crowns, or roots and immediately frozen in liquid nitrogen. All samples were then placed in a freezer $\left(-80^{\circ} \mathrm{C}\right)$ until further analysis.

FATTY ACID ANALYsis. Extraction of fatty acids was performed with $\approx 200 \mathrm{mg}$ (fresh weight) crown, leaf, or root tissue from ice-covered and non-ice-covered samples at $0,20,40$, and $80 \mathrm{~d}$ according to the method of Cyril et al. (2002), with modifications. Frozen crown material was transferred into test tubes containing $3 \mathrm{~mL}$ of preheated isopropanol $\left(75^{\circ} \mathrm{C}\right)$ with $0.01 \%$ butylated hydroxytoluene (BHT). Samples were placed in a $75^{\circ} \mathrm{C}$ water bath for $15 \mathrm{~min}$. After the samples had cooled, $1.5 \mathrm{~mL}$ chloroform and $0.6 \mathrm{~mL}$ distilled water were added, and the samples were capped and shaken at room temperature for 5 $\mathrm{h}$. After $5 \mathrm{~h}$, the lower layer containing chloroform and the lipids were transferred into new test tubes. An additional $4 \mathrm{~mL}$ of chloroform/methanol (2:1) with $0.01 \%$ BHT was added to the tubes containing the crown material. The tubes were recapped and placed on a shaker for $15 \mathrm{~h}$. After extraction, 1 $\mathrm{mL} \mathrm{KCl}$ was added to the tubes containing the extracted lipids and chloroform and was then centrifuged at $5000 \mathrm{~g}_{\mathrm{n}}$ for $10 \mathrm{~min}$. After $10 \mathrm{~min}$, the top layer was removed, $2 \mathrm{~mL}$ of distilled water was added, and the tubes were centrifuged for an additional 10 $\min$ at $5000 g_{\mathrm{n}}$. The top thin layer was removed, and the remaining sample was evaporated using vacuum centrifugation. Samples were preserved in $1 \mathrm{~mL}$ chloroform and stored at $-80{ }^{\circ} \mathrm{C}$ until analysis. Remaining crown material was dried in 
an oven at $70{ }^{\circ} \mathrm{C}$ for determination of dry weight. Gas chromatography mass spectroscopy was performed at the Mass Spectrometry and Metabolomics Core at Michigan State University using a mass selective detector (5975 inert XL MSD detector; Agilent Technologies, Santa Clara, CA). Separation and quantification of fatty acids was achieved by injection of $1 \mu \mathrm{L}$ of extract into a column $[30 \mu \mathrm{m} \times 0.25 \mathrm{~mm} \times 0.25 \mu \mathrm{m}$ (VF-5ms, Agilent Technologies)] using the following temperature profile: $30^{\circ} \mathrm{C}$ for $4 \mathrm{~min} ; 10^{\circ} \mathrm{C} \cdot \mathrm{min}^{-1}$ to $320^{\circ} \mathrm{C} ; 320^{\circ} \mathrm{C}$ for 2 min.

Antioxidant aCtivity AND LIPID PERoxidation. Antioxidant activity was determined by using $250 \mathrm{mg}$ of leaf and crown tissue, which was ground to a fine powder using a mortar and pestle and extracted using $4 \mathrm{~mL}$ of extraction buffer [50 $\mathrm{mm}$ potassium phosphate buffer ( $\mathrm{pH} 7.0)$, and 1\% polyvinylpyrrolidone]. The extractions were centrifuged at $5000 \mathrm{~g}_{\mathrm{n}}$ for $30 \mathrm{~min}$ at $4{ }^{\circ} \mathrm{C}$, and supernatant was collected for subsequent enzyme assay and quantification. Ascorbate peroxidase (APX) activity was measured based on the oxidation of ascorbate as described by Nakano and Asada (1981), with modifications. The reaction solution $(3 \mathrm{~mL})$ contained $100 \mathrm{~mm}$ sodium acetate $(\mathrm{pH} \mathrm{5.8)}$, $0.003 \mathrm{~mm}$ ethylenediaminetetraacetic acid, $10 \mathrm{~mm}$ ascorbate, and $100 \mathrm{~mL}$ leaf extract. The absorbance changes at $290 \mathrm{~nm}$ were measured every $10 \mathrm{~s}$ for $60 \mathrm{~s}$ using a spectrophotometer (GENESYS 10S; Thermo Fisher Scientific, Waltham, MA). The absorbance change of $0.01 / \mathrm{min}$ was taken as one unit of APX activity. The peroxidase (POD) activity was measured by monitoring the increase in absorbency at $460 \mathrm{~nm}$ every $10 \mathrm{~s}$ for $60 \mathrm{~s}$, as guaiacol was oxidized according to the method of Chance and Maehly (1955). The POD reaction solution $(3 \mathrm{~mL})$ contained $0.1 \mathrm{M}$ sodium acetate buffer ( $\mathrm{pH} 5.0$ ), $0.25 \%$ guaiacol (resolved in 50\% ethanol), $0.75 \% \mathrm{H}_{2} \mathrm{O}_{2}$, and 100 $\mathrm{mL}$ of leaf extract. Catalase (CAT) activity was measured by the rate of decomposition of $\mathrm{H}_{2} \mathrm{O}_{2}$ at $240 \mathrm{~nm}$ in $3 \mathrm{~mL}$ of reaction mixture consisting of $50 \mathrm{~mm}$ sodium phosphate buffer and $45 \mathrm{~mm} \mathrm{H}_{2} \mathrm{O}_{2}$ (Chance and Maehly, 1955). Superoxide dismutase (SOD) activity was measured by its ability to inhibit p-nitro-blue tetrazolium chloride reduction at $560 \mathrm{~nm}$ (Giannopolitis and Ries, 1977).

Lipid peroxidation level was determined based on malondialdehyde (MDA) content using the method of Dhindsa et al. (1981), with modifications. A $1.0 \mathrm{~mL}$ enzyme solution was added to $2 \mathrm{~mL}$ of reaction solution containing $20 \%(\mathrm{v} / \mathrm{v})$ trichloroacetic acid and $0.5 \%(\mathrm{v} / \mathrm{v})$ thiobarbituric acid. The solution was heated in a water bath at $95^{\circ} \mathrm{C}$ for $30 \mathrm{~min}$, quickly cooled on ice, and centrifuged at $10,000 \mathrm{~g}_{\mathrm{n}}$ for $30 \mathrm{~min}$. The absorbance readings were taken at $532 \mathrm{~nm}$ and $600 \mathrm{~nm}$. The nonspecific absorbance at $600 \mathrm{~nm}$ was subtracted from absorbance at $532 \mathrm{~nm}$, and MDA content was calculated using the adjusted absorbance and extinction coefficient of 155 $\mathrm{mM}^{-1} \cdot \mathrm{cm}^{-1}$ (Heath and Packer, 1968).

Apoplastic protein Content. Apoplastic proteins were extracted as in the methods of Hon et al. (1994). After harvesting and separating leaf and crown tissue, tissues were rinsed with deionized water and then vacuum-infiltrated with a $20 \mathrm{~mm}$ ascorbic acid and $20 \mathrm{mM} \mathrm{CaCl}_{2}$ solution. This was then centrifuged at $900 g_{n}$ to recover the protein content. The total apoplastic protein content was measured using a Bradford (1976) method assay, using bovine serum albumin as the standard protein.

EXPERIMENTAL DESIGN AND STATISTICAL ANALYSIS. Field plots were arranged as a completely randomized design with four replications. The growth chamber experiment was conducted as a completely randomized block design with ice treatment as the main block. Chemical treatment and sampling time were completely randomized within the main block. The experiment was repeated using the same growth chamber. All data were subjected to analysis of variance (ANOVA) using SAS (version 9.4; SAS Institute, Cary, NC) mixed model procedure (Table 1). Fisher's protected least significant difference (LSD) test at a $0.05 P$ level was used to detect the difference between treatment means. LSD bars were presented in the figures where significant chemical effect was observed. For analyzing the data, time (year and week) was a fixed factor in the model. As ANOVA determined no yearly interaction, data from multiple years was pooled together.

\section{Results}

MDA Content. Leaf and crown tissue had similar levels of lipid peroxidation, and MDA levels increased in both tissues with stress duration. No differences were seen in MDA levels with ACC treatment, compared with controls. Before ice cover at $0 \mathrm{~d}$, ethephon treatments had greater MDA when compared with the untreated control in leaf tissue. After 20 and $40 \mathrm{~d}$ of ice-covered annual bluegrass, ethephon treatment had 154\% and $79 \%$ more lipid peroxidation when compared with the untreated control, respectively, in leaf tissue (Fig. 1A). After 20

Table 1. Analysis of variance for main treatment factors and interactions of percent regrowth, fatty acid content, antioxidant enzymes [ascorbate peroxidase (APX), superoxide dismutase (SOD), peroxidase (POD), and catalase (CAT)], lipid peroxidation, and apoplastic protein concentrations of annual bluegrass under ethylene and ethylene inhibition treatments and ice or no ice cover treatments in East Lansing, MI during 2016 and 2017.

\begin{tabular}{|c|c|c|c|c|c|c|c|c|c|c|c|c|c|c|}
\hline \multirow[b]{2}{*}{ Effect $^{z}$} & \multicolumn{3}{|c|}{ Fatty acid content } & \multicolumn{2}{|c|}{ APX } & \multicolumn{2}{|c|}{ SOD } & \multicolumn{2}{|c|}{ POD } & \multicolumn{2}{|c|}{ CAT } & \multicolumn{2}{|c|}{$\mathrm{MDA}^{\mathrm{y}}$} & \multirow{2}{*}{$\frac{\text { Proteins }}{\text { Crown }}$} \\
\hline & Leaf & Crown & $\overline{\text { Leaf }}$ & $\overline{\text { Crown }}$ & $\overline{\text { Leaf }}$ & $\overline{\text { Crown }}$ & $\overline{\text { Leaf }}$ & $\overline{\text { Crown }}$ & $\overline{\text { Leaf }}$ & $\overline{\text { Crown }}$ & $\overline{\text { Leaf }}$ & $\overline{\text { Crown }}$ & $\overline{\text { Leaf }}$ & \\
\hline Chemical treatment (T) & $* * *$ & $* * *$ & $* * *$ & $* * *$ & $* * *$ & $* *$ & $* * *$ & $* *$ & $* *$ & $* * *$ & $* * *$ & $* *$ & $* * *$ & $* *$ \\
\hline Ice cover treatment (I) & NS & NS & $*$ & $*$ & $*$ & $* *$ & $* *$ & $* * *$ & $* *$ & $* *$ & $* * *$ & $* * *$ & NS & NS \\
\hline $\mathrm{T} \times \mathrm{I}$ & NS & NS & NS & NS & NS & NS & NS & NS & NS & NS & NS & NS & NS & NS \\
\hline Date (D) & $* * *$ & $* * *$ & $* *$ & $* *$ & $* *$ & $* *$ & $* * *$ & $*$ & $* *$ & $*$ & $* * *$ & $* *$ & $* *$ & $* *$ \\
\hline $\mathrm{T} \times \mathrm{D}$ & $* *$ & $* * *$ & $* *$ & $*$ & $* * *$ & $*$ & $* *$ & $* * *$ & $* *$ & $* * *$ & $* * *$ & $* * *$ & $* *$ & $*$ \\
\hline $\mathrm{I} \times \mathrm{D}$ & NS & NS & NS & NS & NS & NS & NS & NS & NS & NS & NS & NS & NS & NS \\
\hline $\mathrm{T} \times \mathrm{I} \times \mathrm{D}$ & NS & NS & NS & NS & NS & NS & NS & NS & NS & NS & NS & NS & NS & NS \\
\hline
\end{tabular}

${ }^{\mathrm{z}}$ All data were subjected to ANOVA using a mixed model procedure.

${ }^{\mathrm{y}}$ Lipid peroxidation was estimated by measuring malondialdehyde (MDA) content.

NS, ${ }^{*}, * *, * *$ Nonsignificant $(P>0.05)$ or significant at $P \leq 0.05,0.01$, or 0.001 , respectively. 

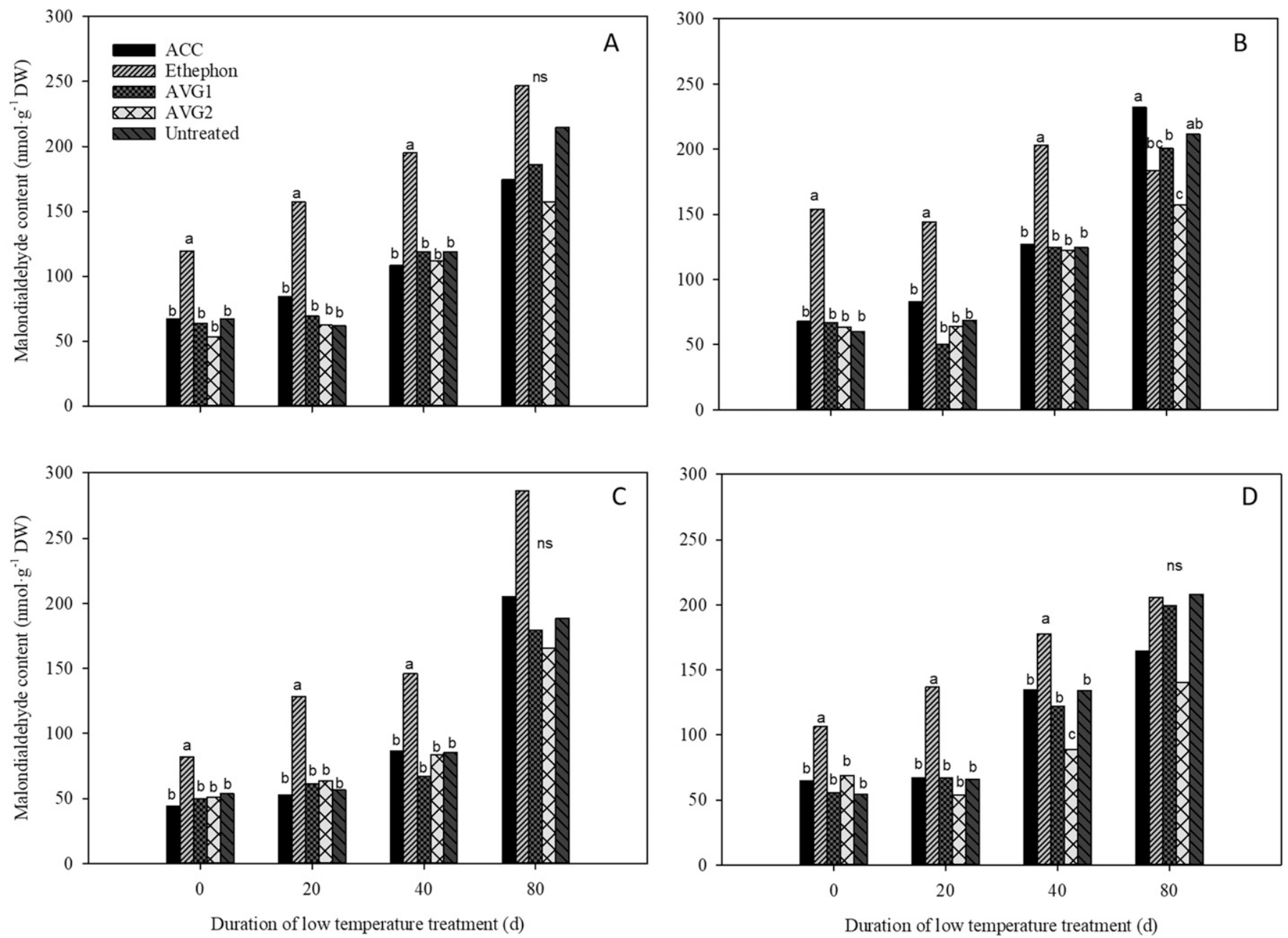

Fig. 1. Malondialdehyde (MDA) content of annual bluegrass treated with 1-aminocyclopropane-1-carboxylic acid (ACC), ethephon, aminoethoxyvinylglycine (AVG) at $33.9 \mathrm{~g} \cdot \mathrm{ha}^{-1}$ (AVG1), and $2.915 \mathrm{~g} \cdot \mathrm{ha}^{-1}$ (AVG2), or untreated after $0,20,40$, and $80 \mathrm{~d}$ at $-4{ }^{\circ} \mathrm{C}$ in leaf tissue under (A) ice cover or (B) no ice cover, and in crown tissue under $(\mathbf{C})$ ice cover or (D) no ice cover. Means from both 2016 and 2017 are pooled together. Bars with different letters are significantly different $(P \leq 0.05)$ due to treatment within a given day based on Fisher's protected least significant difference tests.

and $40 \mathrm{~d}$ of non-ice-covered annual bluegrass, ethephon treatment had $110 \%$ and $62.8 \%$ more malondialdehyde content when compared with the untreated control, respectively, in leaf tissue (Fig. 1B). In crown tissue under ice and no ice cover, ethephon treatment had greater malondialdehyde content when compared with the untreated control at 0,20 , and $40 \mathrm{~d}$ (Fig. 1C-D).

Catalase activity. In leaf tissue of annual bluegrass, AVG2 treatment increased CAT after 40 and $80 \mathrm{~d}$ of non-icecovered samples by $17.9 \%$ and $34.1 \%$, respectively, when compared with the untreated control (Fig. 2B). AVG1- and ACC-treated plants were not significantly different in CAT activity than the AVG2 treatment. In leaf tissue that was covered by ice, AVG2 treatment increased CAT activity by $40.6 \%$ after $80 \mathrm{~d}$ when compared with the untreated control (Fig. 2A). In crown tissue, AVG1- and AVG2-treated annual bluegrass had greater CAT when compared with the untreated control after $40 \mathrm{~d}$ of no ice cover (Fig. 2D). CAT was $74.5 \%$ greater in samples treated with AVG2 when compared with the untreated control after $40 \mathrm{~d}$ without ice cover. After $80 \mathrm{~d}$ with ice cover, AVG1-treated annual bluegrass had $34.9 \%$ greater CAT activity when compared with the untreated control (Fig. 2C).
SuPEROXIDE DISMUTASE ACTIVITY. Before ice treatment, ethephon treatment had less superoxide dismutase activity when compared with the untreated control in leaf tissue of annual bluegrass. After 40 and $80 \mathrm{~d}$ of ice cover, SOD activity of annual bluegrass was $32 \%$ and $38 \%$ less for ethephon treatment, respectively, when compared with the untreated control (Fig. $3 \mathrm{~A})$. After $20 \mathrm{~d}$ with no ice cover, ethephon treatment had $27.9 \%$ less SOD activity when compared with the untreated control, while AVG2 treatment had $16.7 \%$ more SOD activity in leaf tissue (Fig. 3B). After $80 \mathrm{~d}$ with no ice cover, ethephon treatment had $40.9 \%$ less SOD activity in leaf tissue when compared with the untreated control. In crown tissue after 40 and $80 \mathrm{~d}$ of ice cover, ACC treatment had $26.6 \%$ and $19.2 \%$ greater SOD activity when compared with the untreated control (Fig. 3C). The AVG2 treatment after $80 \mathrm{~d}$ of ice cover had $42.9 \%$ less SOD activity. After $80 \mathrm{~d}$ of no ice cover, AVG2 had $31 \%$ more SOD activity when compared with the untreated control, while ethephon treatment had $37.4 \%$ less SOD activity in crown tissue (Fig. 3D).

Peroxidase aCtivity. Ethephon treatment decreased POD when compared with the untreated control before ice cover (day 

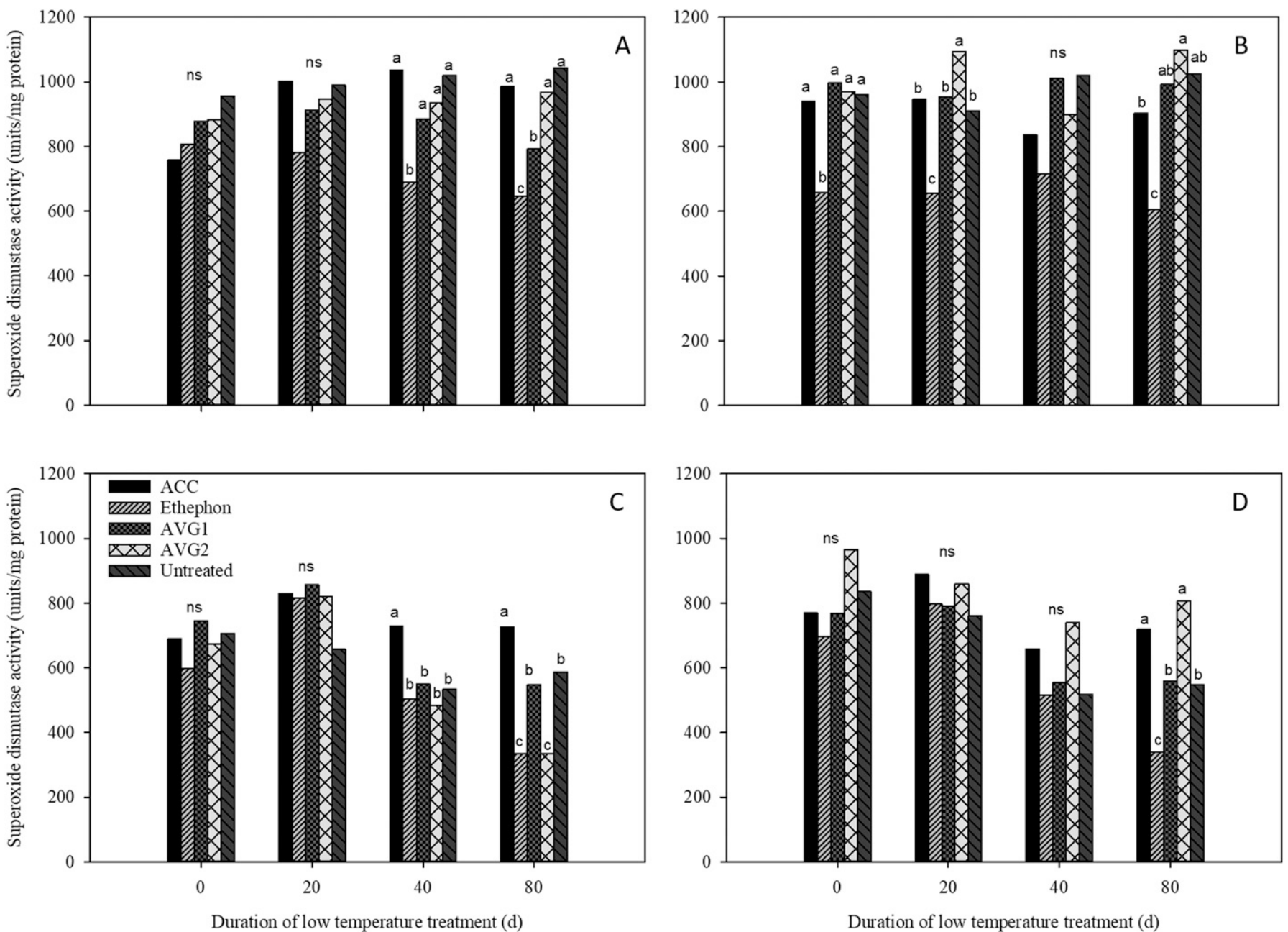

Fig. 2. Catalase (CAT) activity of annual bluegrass treated with 1-aminocyclopropane-1-carboxylic acid (ACC), ethephon, aminoethoxyvinylglycine (AVG) at 33.9 $\mathrm{g} \cdot \mathrm{ha}^{-1}$ (AVG1), and $2.915 \mathrm{~g} \cdot \mathrm{ha}^{-1}$ (AVG2), or untreated after $0,20,40$, and $80 \mathrm{~d}$ at $-4{ }^{\circ} \mathrm{C}$ in (A) leaf tissue under ice cover or (B) no ice cover, and in $(\mathbf{C})$ crown tissue under ice cover or (D) no ice cover. Means from both 2016 and 2017 are pooled together. Bars with different letters are significantly different $(P \leq 0.05)$ due to treatment within a given day based on Fisher's protected least significant difference tests.

0) by $24.2 \%$ in leaf tissue. After $20 \mathrm{~d}$ of ice cover, ethephon treatments had $28.3 \%$ less POD activity when compared with the untreated control in leaf tissue (Fig. 4A). After $80 \mathrm{~d}$ of ice cover, ethephon treatment had $32.3 \%$ less POD activity when compared with the untreated control, while the AVG2 treatment had $26.4 \%$ higher POD activity in leaf tissue when compared with the untreated control. AVG1-treated annual bluegrass had higher POD activity when compared with the untreated control at $80 \mathrm{~d}$ of ice cover in leaf tissue. In crown tissue before ice cover, ethephon treatment had $26.6 \%$ less POD activity. Ethephon treatment in crown tissue after 20 and $80 \mathrm{~d}$ of ice cover had $42.3 \%$ and $52 \%$ less POD activity, respectively, when compared with the untreated control (Fig. 4C).

Ascorbate Peroxidase aCtivity. APX levels were generally greater in crown tissue than in leaf tissue. Few significant differences in APX activity were detected among chemical treatments. In leaf tissue, AVG2 treatment increased APX activity after $80 \mathrm{~d}$ by $40 \%$ and $160 \%$ in ice cover and non-icecovered treatments, respectively (Fig. 5A). In crown tissue, AVG2-treated plots had greater APX activity than controls after $80 \mathrm{~d}$ in non-ice-covered annual bluegrass after 40 and $80 \mathrm{~d}$
(Fig. 5B). No consistent differences were found for the other chemical treatments for APX activity.

Apoplastic proteins. Apoplastic protein concentrations increased in leaf and crown tissue over time. In leaf tissue, apoplastic protein concentration increased until about $40 \mathrm{~d}$ of low-temperature treatment. In crown tissue, apoplastic protein concentrations increased up to $80 \mathrm{~d}$ of low-temperature treatment. After 20, 40, and $80 \mathrm{~d}$ at $-4{ }^{\circ} \mathrm{C}$, AVG1- and AVG2-treated plants had greater apoplastic protein concentrations when compared with the untreated control in leaf tissue (Fig. 6A). In crown tissue on day 80, all treatments applied to annual bluegrass had greater apoplastic protein concentrations when compared with the untreated control. AVG1-treated annual bluegrass had $40 \%$ greater apoplastic protein concentration when compared with ethephontreated annual bluegrass (Fig. 6B).

FatTy ACIDS. Six fatty acids, including unsaturated and saturated, were detected in leaf, crown, and root tissues of annual bluegrass plants. The saturated fatty acids included palmitic acid (16:0) and stearic acid (18:0). The monounsaturated fatty acids were palmitoleic acid (16:1) and oleic acid (18:1), and the polyunsaturated fatty acids were linoleic acid (18:2) and $\alpha$-linolenic 

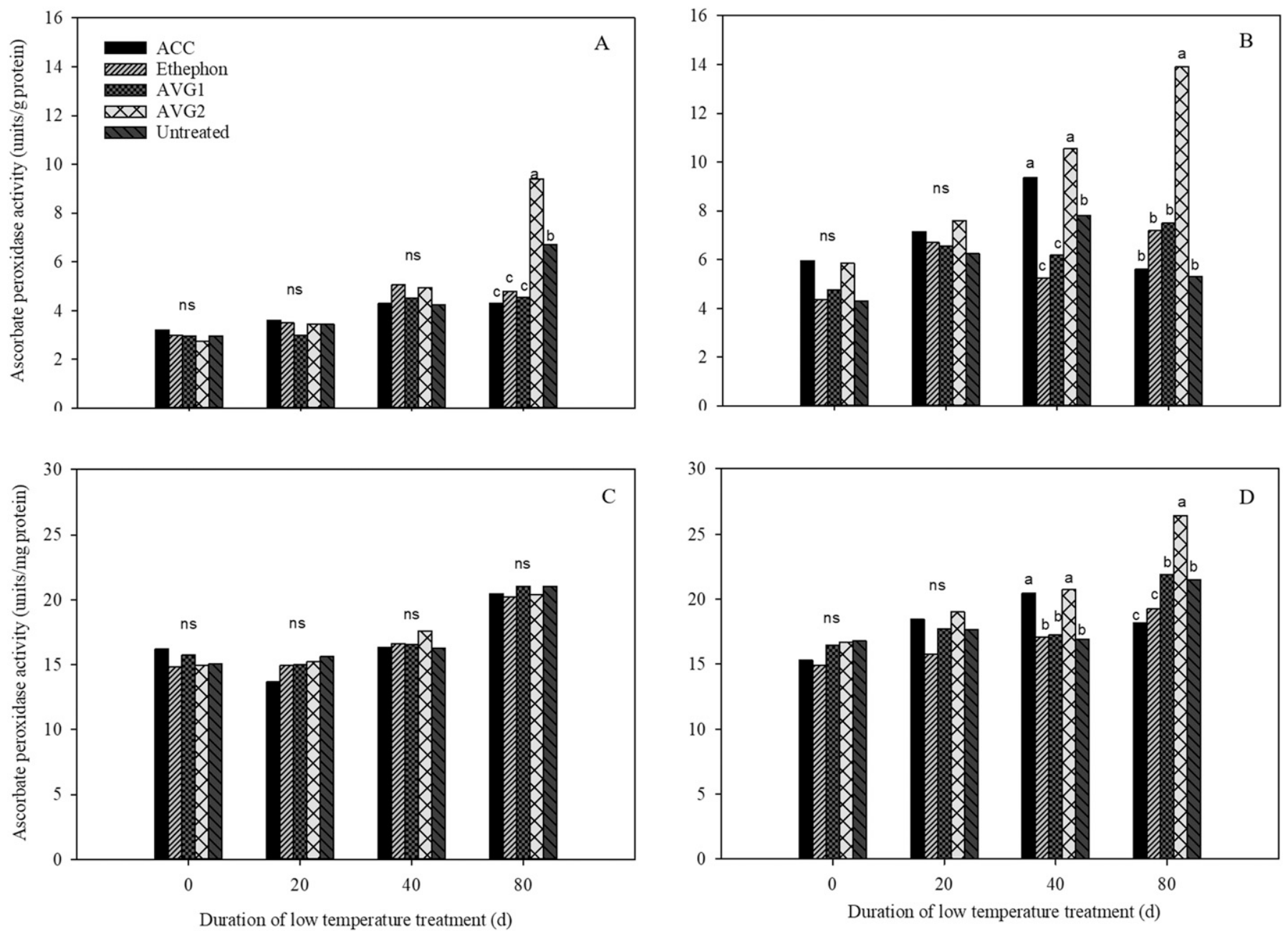

Fig. 3. Superoxide dismutase (SOD) activity of annual bluegrass treated with 1-aminocyclopropane-1-carboxylic acid (ACC), ethephon, aminoethoxyvinylglycine (AVG) at $33.9 \mathrm{~g} \cdot \mathrm{ha}^{-1}$ (AVG1), and $2.915 \mathrm{~g} \cdot \mathrm{ha}^{-1}$ (AVG2), or untreated after $0,20,40$, and $80 \mathrm{~d}$ at $-4{ }^{\circ} \mathrm{C}$ in leaf tissue under (A) ice cover or (B) no ice cover, and in crown tissue under $(\mathbf{C})$ ice cover or $(\mathbf{D})$ no ice cover. Means from both 2016 and 2017 are pooled together. Bars with different letters are significantly different $(P \leq 0.05)$ due to treatment within a given day based on Fisher's protected least significant difference tests.

acid (18:3). The fatty acid hexadecadienoic acid (16:2) was not observed in measurable quantities. Significant effects from PGR treatments were observed on fatty acid composition of annual bluegrass crown membrane profiles and were consistent for each time point of sampling $(0,20,40$, or $80 \mathrm{~d}$ of low-temperature or ice treatment). Ice-treatment duration and ice treatment did not change fatty acid composition within a given treatment. Statistical analysis indicated differences among sampling day, resulting in data being presented separately by sampling day. Ice-cover treatment was not statistically significant, resulting in data being pooled together for ice-cover treatment.

Before ice encasement and low-temperature treatments, leaf, crown, and root tissue fatty acids were analyzed at day 0 . Overall, ethylene inhibition treatments decreased saturated fatty acid concentrations and increased unsaturated fatty acid concentrations in leaf and crown tissue. In leaf tissue, AVG1treated annual bluegrass had increased oleic acid content when compared with the untreated control (Table 2). In crown tissue at $0 \mathrm{~d}$, AVG1-treated annual bluegrass had lower palmitic acid and stearic acid when compared with the untreated control. For example, AVG1-treated annual bluegrass had 16\% lower palmitic acid and 19\% lower stearic acid content in crown tissue on $0 \mathrm{~d}$ when compared with the untreated control. In root tissue, both ethephon and ACC-treated annual bluegrass had lower linoleic acid contents when compared with the untreated control (Table 2).

Ethylene inhibitory treatments increased unsaturated fatty acid concentrations in leaf tissue and decreased saturated fatty acid concentrations in crown tissue when compared with the untreated control, when measured at $20 \mathrm{~d}$ in the low-temperature chamber (Tables 2 and 3). AVG1-treated annual bluegrass had greater oleic acid content than the untreated control in leaf tissue (Table 2). In crown tissue, AVG1-treated annual bluegrass had $13 \%$ less palmitic acid content when compared with the untreated control (Table 3). In root tissue, AVG2-treated annual bluegrass had less stearic acid content when compared with the untreated control (Table 2). In crown tissue, AVG1treated annual bluegrass had $18 \%$ less palmitic acid content and $24 \%$ greater palmitoleic acid content when compared with the untreated control after $40 \mathrm{~d}$ of low-temperature treatment (Table 3). In root tissue, AVG1- and AVG2-treated annual bluegrass had $25 \%$ and $20 \%$ less palmitic acid content when compared with the untreated control, respectively (Table 2). AVG1- and AVG2-treated annual bluegrass had lower palmitic 

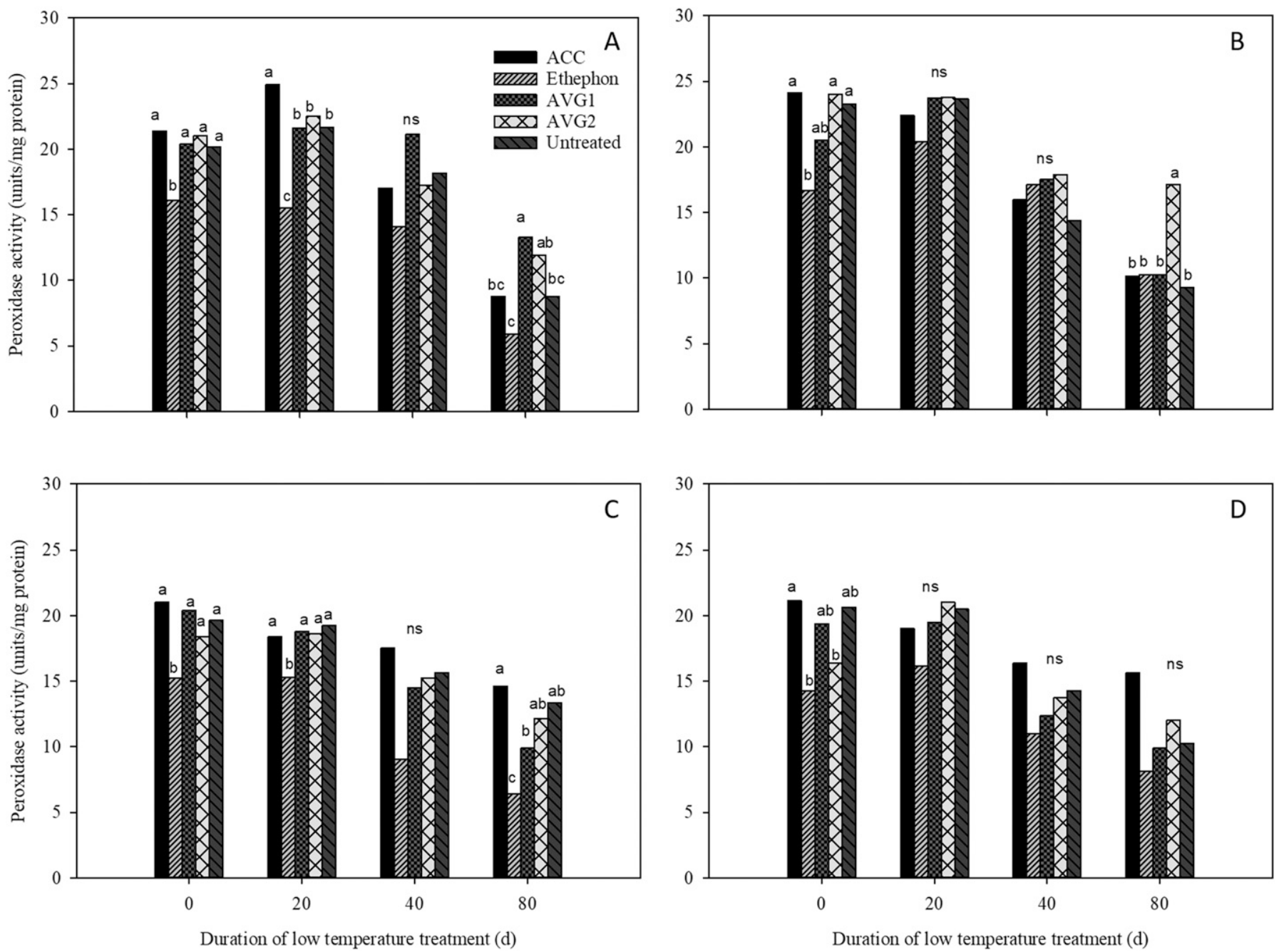

Fig. 4. Peroxidase activity of annual bluegrass treated with 1-aminocyclopropane-1-carboxylic acid (ACC), ethephon, aminoethoxyvinylglycine (AVG) at 33.9 g.ha ${ }^{-1}$ (AVG1), and $2.915 \mathrm{~g} \cdot \mathrm{ha}^{-1}$ (AVG2), or untreated after $0,20,40$, and $80 \mathrm{~d}$ at $-4{ }^{\circ} \mathrm{C}$ in leaf tissue under (A) ice cover or (B) no ice cover, and in crown tissue under $(\mathbf{C})$ ice cover or $(\mathbf{D})$ no ice cover. Means from both 2016 and 2017 are pooled together. Bars with different letters are significantly different $(P \leq 0.05)$ due to treatment within a given day based on Fisher's protected least significant difference tests.

acid after $80 \mathrm{~d}$ of low-temperature treatment in both leaf and crown tissue when compared with the untreated control (Table 2). AVG1 also had $33 \%$ and $19 \%$ greater linoleic acid content in leaf and crown tissue when compared with the untreated control, respectively, and $13 \%$ greater linolenic acid content in crown tissue. In root tissue, annual bluegrass treated with AVG1 and AVG2 had 39\% and 32\% greater oleic acid content, respectively, when compared with the untreated controls (Table 3).

Ethylene treatment of annual bluegrass significantly altered fatty acid composition of leaf, crown, and root tissue. Ethephon-treated annual bluegrass exhibited lower unsaturated fatty acid concentrations when compared with the untreated control plants after $20 \mathrm{~d}$ under low-temperature treatment. For example, ethephon treatment had 17\% less palmitoleic acid and 23\% less oleic acid content when compared with the untreated control in crown tissue (Table 3). Ethephon treatment had $39 \%$ greater stearic acid when compared with the untreated control after $40 \mathrm{~d}$ of low-temperature treatment in leaf tissue (Table 2). Ethephon-treated annual bluegrass had 32\% less oleic and linolenic acid content when compared with the untreated control in root tissue (Table 3). Ethephon-treated annual bluegrass had $48 \%$ greater stearic acid content in leaf tissue and $18 \%$ greater stearic acid content in crown tissue when compared with the untreated controls after $80 \mathrm{~d}$ of lowtemperature treatment (Table 2).

\section{Discussion}

Plant growth or cellular survival at low temperatures can cause oxidative stress or the production of stressful levels of reactive oxygen species [ROS (Okuda et al., 1991)], which can lead to lipid peroxidation (Thomashow, 1999). Ice encasement can lead to anoxic conditions that may alleviate some oxidative stress associated with cold; but when ice melts, oxygen concentration can rapidly increase and require a major shift in antioxidant systems for cell survival. Antioxidant system responses may play a major role in ice-encasement survival (Blokhina et al., 1999). In this study, growth-chambersimulated low-temperature alone, and ice encasement under low-temperature conditions, caused an increase in lipid peroxidation over time, with increasing duration of low-temperature 

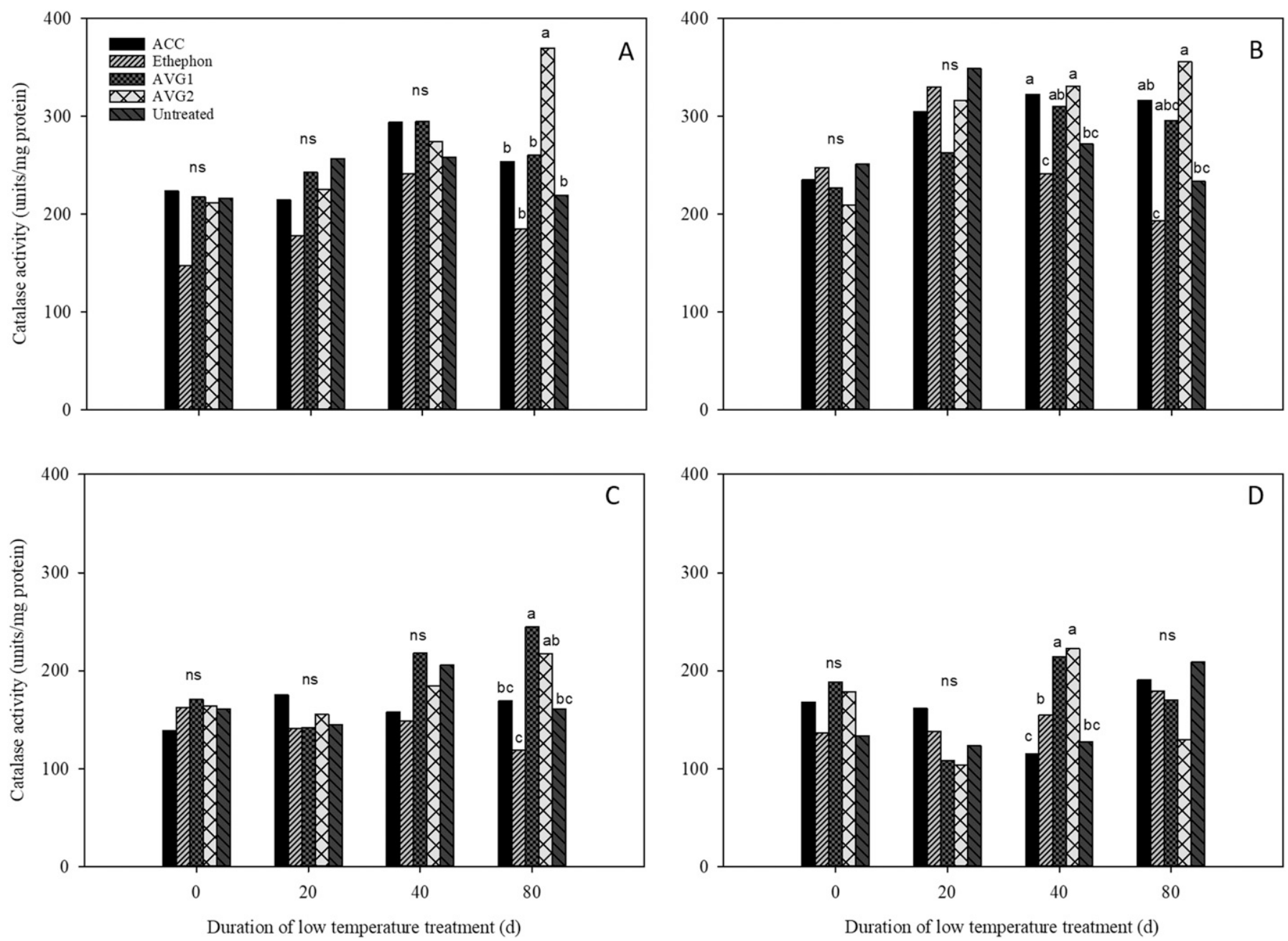

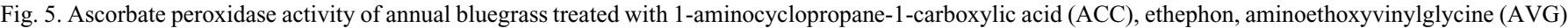
at $33.9 \mathrm{~g} \cdot \mathrm{ha}^{-1}$ (AVG1), and $2.915 \mathrm{~g} \cdot \mathrm{ha}^{-1}$ (AVG2), or untreated after $0,20,40$, and $80 \mathrm{~d}$ at $-4{ }^{\circ} \mathrm{C}$ in leaf tissue under $(\mathbf{A})$ ice cover or $(\mathbf{B})$ no ice cover, and in crown tissue under $(\mathbf{C})$ ice cover or $(\mathbf{D})$ no ice cover. Means from both 2016 and 2017 are pooled together. Bars with different letters are significantly different $(P \leq 0.05)$ due to treatment within a given day based on Fisher's protected least significant difference tests.

or ice-encasement treatment in both leaves and crowns. The average levels of MDA were similar in both leaf and crown tissue. This means that, surprisingly, crowns were not more resistant to the development of lipid peroxidation than leaves. This could mean that systems that protect these membranes, such as antioxidant and other lipid-restorative pathways, are important for survival and that additional research of annual bluegrass lipid-protection mechanisms would have merit.

Regarding the growth-regulator treatment responses of lipid peroxidation, ethylene treatments were associated with greater levels of lipid peroxidation in annual bluegrass under ice and no ice cover. Thus, it may be possible that limiting ethylene production during acclimation could lead to enhanced survival of grass species overwinter through reduced lipid damages. Ethephon treatment at this rate is causing some additional physiological damage to lipid structure during these overwintering treatments. The pure ACC treatment did not cause this increase, which could be related to formulation or retention of treatment effects compared with the commercial formulation. Ethylene inhibition treatments did reduce lipid peroxidation of crown and leaf tissues but only under no ice conditions.
The presence of ice or no ice seemed to play a role in how lipid peroxidation responded to ethylene regulatory treatments, but the total amount of lipid peroxidation was not different between the ice and no ice conditions. This could be related to the amount of available oxygen, because oxygen may be more limited under ice conditions. Additional investigation of rates and timing of ethylene inhibitory treatments may be important to see enhanced protection from lipid peroxidation during winter stresses.

To combat lipid peroxidation and other oxidative stress damages, the health of a plant tissue's antioxidant system is important for winter survival. SOD and POD were consistently reduced in ethephon-treated leaf and crown tissues under ice and in low-temperature conditions with no ice cover. APX levels were generally higher in crown tissue compared with leaf tissues. CAT activity was generally higher in leaf tissue compared with crown tissue. Thus, for each tissue type, the relative importance of each antioxidant enzyme seems to be different. For annual bluegrass crowns, which are the major overwintering structure, maintenance of APX may naturally be more important than in leaf tissue. It is not yet clear whether 

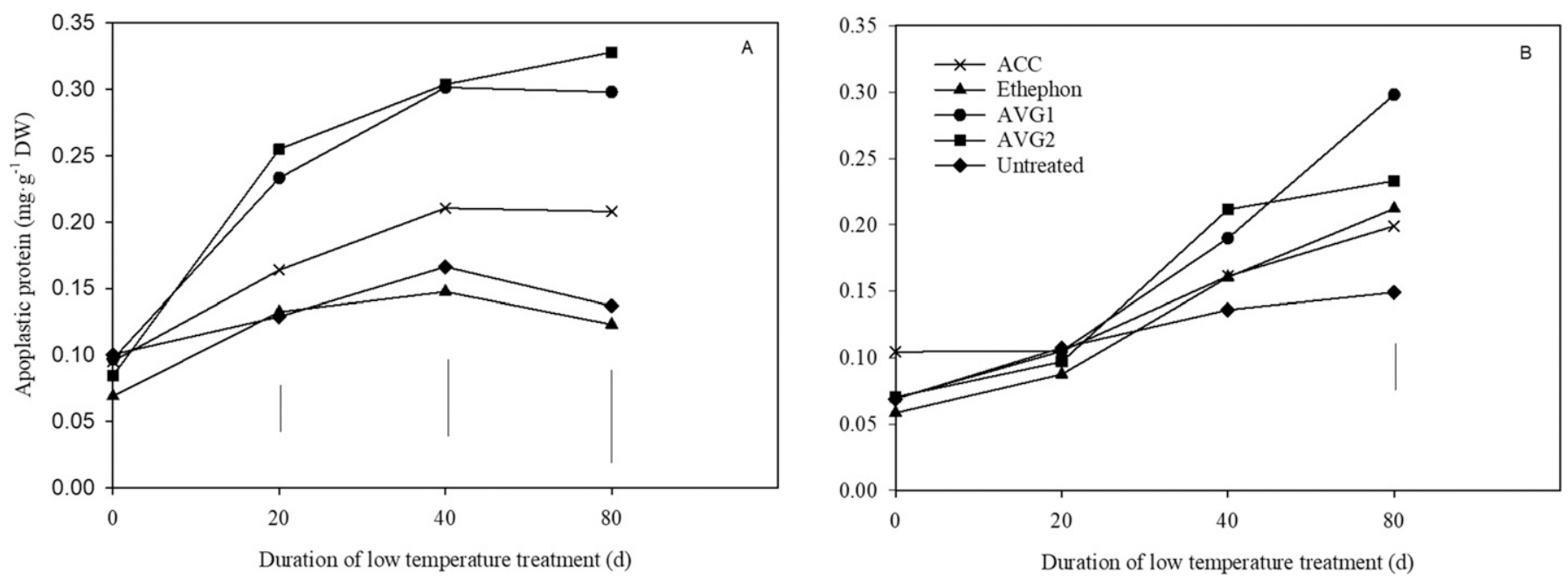

Fig. 6. Apoplastic protein content of annual bluegrass treated with 1-aminocyclopropane-1-carboxylic acid (ACC), ethephon, aminoethoxyvinylglycine (AVG) at $33.9 \mathrm{~g} \cdot \mathrm{ha}^{-1}$ (AVG1), and $2.915 \mathrm{~g} \cdot \mathrm{ha}^{-1}$ (AVG2), or untreated after $0,20,40$, and $80 \mathrm{~d}$ at $-4{ }^{\circ} \mathrm{C}$ in (A) leaf tissue and in (B) crown tissue. Means from both 2016 and 2017 and from ice cover treatments are pooled together. Least significant difference (LSD) values are indicated by vertical bars $(P \leq 0.05)$ for treatment comparisons on a given day of treatment based on Fisher's protected LSD tests.

Table 2. Changes in the saturated fatty acid contents of leaf, crown, and root tissue of annual bluegrass treated with ethylene regulatory treatments or untreated. Annual bluegrass plants were exposed to $0,20,40$, or $80 \mathrm{~d}$ in a low-temperature growth chamber $\left(-4{ }^{\circ} \mathrm{C}\right)$ and treated with ice encasement or no ice encasement. Means from both 2016 and 2017 are pooled together. Ice and no ice cover treatment means are pooled together.

\begin{tabular}{|c|c|c|c|c|c|c|c|c|c|c|c|c|}
\hline & \multicolumn{4}{|c|}{ Leaf } & \multicolumn{4}{|c|}{ Crown } & \multicolumn{4}{|c|}{ Root } \\
\hline & \multicolumn{12}{|c|}{ Duration of stress treatment $(\mathrm{d})$} \\
\hline & 0 & 20 & 40 & 80 & 0 & 20 & 40 & 80 & 0 & 20 & 40 & 80 \\
\hline$\overline{16: 0^{z}}$ & \multicolumn{12}{|c|}{ Saturated fatty acid content $(\mathrm{mol} \%)^{\mathrm{y}}$} \\
\hline Ethephon & 10.3 & 16.6 & 19.2 & $25.0 \mathrm{a}$ & $37.8 \mathrm{ab}$ & $39.9 \mathrm{a}$ & $45.8 \mathrm{a}$ & $43.2 \mathrm{ab}$ & 27.3 & 29.1 & $30.7 \mathrm{abc}$ & 28.7 \\
\hline AVG1 & 14 & 16.6 & 17.8 & $16.2 \mathrm{~b}$ & $32.3 \mathrm{~b}$ & $36.9 \mathrm{~b}$ & $36.4 \mathrm{c}$ & $35.5 \mathrm{c}$ & 25.4 & 25.5 & $24.6 \mathrm{c}$ & 27.3 \\
\hline AVG2 & 11.9 & 16.9 & 17.5 & $14.6 \mathrm{~b}$ & $42.7 \mathrm{a}$ & $40.7 \mathrm{a}$ & $39.5 \mathrm{bc}$ & $35.1 \mathrm{c}$ & 28.7 & 27.6 & $26.4 \mathrm{bc}$ & 25.5 \\
\hline \multicolumn{13}{|l|}{$18: 0$} \\
\hline $\mathrm{ACC}$ & $3.8 \mathrm{ab}$ & 4 & $3.2 \mathrm{~b}$ & $2.8 \mathrm{bc}$ & $21.6 \mathrm{a}$ & 19.1 & $36.2 \mathrm{a}$ & $21.1 \mathrm{bc}$ & 3.7 & 7.1 & 6.4 & 5.8 \\
\hline Ethephon & $3.2 \mathrm{~b}$ & 4.3 & $5.1 \mathrm{a}$ & $5.5 \mathrm{a}$ & $22.1 \mathrm{a}$ & 13.6 & $25.4 \mathrm{~b}$ & $28.5 \mathrm{a}$ & 3.3 & 6.4 & 5.7 & 6.6 \\
\hline AVG1 & $2.5 \mathrm{~b}$ & 5 & $3.7 \mathrm{ab}$ & $3.4 \mathrm{~b}$ & $17.2 \mathrm{~b}$ & 13.8 & $25.7 \mathrm{~b}$ & $19.1 \mathrm{c}$ & 3.1 & 6.3 & 5.8 & 5.7 \\
\hline AVG2 & $3.2 \mathrm{~b}$ & 4.6 & $3.6 \mathrm{ab}$ & $3.6 \mathrm{~b}$ & $19.3 \mathrm{ab}$ & 13.3 & $23.6 \mathrm{bc}$ & $22.3 \mathrm{bc}$ & 2.3 & 5.8 & 6.2 & 7 \\
\hline Untreated & $2.3 \mathrm{~b}$ & 4 & $3.1 \mathrm{~b}$ & $2.9 \mathrm{bc}$ & $21.4 \mathrm{a}$ & 13 & $24.3 \mathrm{bc}$ & $23.3 \mathrm{~b}$ & 3.1 & 6.5 & 6.7 & 7.3 \\
\hline
\end{tabular}

${ }^{\mathrm{z}}$ Levels of the saturated fatty acids palmitic acid (16:0) and stearic acid (18:0).

${ }^{\mathrm{y}}$ Within each column for each fatty acid, means followed by the same letter are not significantly different $(P \leq 0.05)$. Fisher's protected least significant difference test at a $0.05 P$ level was used to detect the difference between treatment means. Columns with no letters indicate no significant differences among chemical treatments.

${ }^{\mathrm{x}}$ Chemical treatments of aminocyclopropane-1-carboxylic acid (ACC), $33.9 \mathrm{~g} \cdot \mathrm{ha}^{-1}$ aminoethoxyvinylglycine (AVG1), and 2.915 g.ha ${ }^{-1}$ AVG (AVG2).

technologies that could improve CAT activity in crowns would be a benefit to overwintering plants or not.

Some of the antioxidant enzymes evaluated in this study did significantly change in response to ethylene regulatory treatments. APX and CAT were not greatly affected by ethylene treatment. Ethylene inhibitors may have indirectly or directly promoted preservation of antioxidant enzymes. SOD and POD activity were preserved closer to $0 \mathrm{~d}$ control levels to a greater extent in plants treated with AVG2, and APX and CAT activity was promoted by AVG2 treatment. Taşgin et al. (2006) investigated the response of several antioxidant enzymes to cold treatment of winter wheat and found CAT to decline and peroxidase to increase with cold treatment. It is possible that maintenance or promotion of the levels of these antioxidants played a significant role in the survival of annual bluegrass to these simulated winter conditions.

How ethylene treatments may affect fatty acid changes during cold acclimation is not well understood or may be differential in various plant species. Munshaw et al. (2010) found that ethephon treatment in the fall had no effect on freeze tolerance of bermudagrass (Cynodon dactylon), there were no effects on lipid unsaturation levels, and no changes in the level of linolenic acid due to ethephon treatment were detected. Linolenic acid may be an important fatty acid for grass cold 
Table 3. Changes in the unsaturated fatty acid contents of leaf, crown, and root tissue of annual bluegrass treated with ethylene regulatory treatments or untreated. Annual bluegrass plants were exposed to $0,20,40$, or $80 \mathrm{~d}$ in a low-temperature growth chamber $\left(-4{ }^{\circ} \mathrm{C}\right)$ and treated with ice encasement or no ice encasement. Means from both 2016 and 2017 are pooled together. Ice and no ice cover treatment means are pooled together.

\begin{tabular}{|c|c|c|c|c|c|c|c|c|c|c|c|c|}
\hline & \multicolumn{4}{|c|}{ Leaf } & \multicolumn{4}{|c|}{ Crown } & \multicolumn{4}{|c|}{ Root } \\
\hline & \multicolumn{12}{|c|}{ Duration of stress treatment $(\mathrm{d})$} \\
\hline & 0 & 20 & 40 & 80 & 0 & 20 & 40 & 80 & 0 & 20 & 40 & 80 \\
\hline $16: 1^{z}$ & \multicolumn{12}{|c|}{ Unsaturated fatty acid content $(\mathrm{mol} \%)^{\mathrm{y}}$} \\
\hline Ethephon & 3.4 & 4.5 & 5.3 & $5.1 \mathrm{~b}$ & 2 & $10.4 \mathrm{~d}$ & $1.8 \mathrm{bc}$ & 1.8 & 3.6 & 0.7 & 0.8 & 1 \\
\hline AVG1 & 5.1 & 4.2 & 6.3 & $6.4 \mathrm{a}$ & 1.4 & $12.3 \mathrm{ab}$ & $2.3 \mathrm{~b}$ & 2 & 2.6 & 0.9 & 1 & 0.9 \\
\hline AVG2 & 5 & 3.7 & 4.5 & $5.1 \mathrm{~b}$ & 2.3 & $11.9 \mathrm{bc}$ & $1.6 \mathrm{c}$ & 1.5 & 3.2 & 0.7 & 0.6 & 0.8 \\
\hline \multicolumn{13}{|l|}{$18: 1$} \\
\hline $\mathrm{ACC}$ & $1.8 \mathrm{ab}$ & $2.0 \mathrm{bc}$ & 2.2 & 1.8 & 2.4 & $2.6 \mathrm{ab}$ & 2.7 & 2.2 & 10.8 & 11 & $9.7 \mathrm{a}$ & $9.9 \mathrm{a}$ \\
\hline Ethephon & $1.9 \mathrm{ab}$ & $2.4 \mathrm{ab}$ & 2.3 & 2.2 & 2.3 & $2.1 \mathrm{~b}$ & 2.3 & 2.7 & 8.4 & 11.5 & $6.8 \mathrm{~b}$ & $9.3 \mathrm{ab}$ \\
\hline AVG1 & $2.7 \mathrm{a}$ & $2.7 \mathrm{a}$ & 2.9 & 2.5 & 3.2 & $2.7 \mathrm{ab}$ & 2.3 & 2.6 & 12.1 & 11.2 & $10.4 \mathrm{a}$ & $11.8 \mathrm{a}$ \\
\hline AVG2 & $2.2 \mathrm{a}$ & $1.6 \mathrm{c}$ & 1.9 & 1.1 & 3.3 & $3.4 \mathrm{a}$ & 3.4 & 3.4 & 9.3 & 11.5 & $11.0 \mathrm{a}$ & $9.7 \mathrm{ab}$ \\
\hline Untreated & $1.8 \mathrm{ab}$ & $2.0 \mathrm{bc}$ & 2.4 & 1.8 & 2.8 & $2.7 \mathrm{ab}$ & 2.7 & 2.6 & 7.7 & 7.6 & $11.7 \mathrm{a}$ & $7.2 \mathrm{~b}$ \\
\hline AVG2 & 13.6 & 14.4 & 13.8 & $7.1 \mathrm{~b}$ & 19.6 & $18.7 \mathrm{ab}$ & $15.6 \mathrm{~b}$ & $11.6 \mathrm{~d}$ & $35.7 \mathrm{~b}$ & 37.1 & 36.2 & 36.2 \\
\hline Untreated & 15.4 & 13.1 & 9.4 & $10.6 \mathrm{~b}$ & 19.3 & $17.1 \mathrm{~b}$ & $15.3 \mathrm{~b}$ & $16.8 \mathrm{~b}$ & $34.7 \mathrm{bc}$ & 39.1 & 36.7 & 36.6 \\
\hline \multicolumn{13}{|l|}{$18: 3$} \\
\hline $\mathrm{ACC}$ & 44.2 & 44.7 & 46.9 & 43.8 & 14 & 14.7 & 13.8 & $13.3 \mathrm{~cd}$ & 15.1 & 14.2 & $14.6 \mathrm{a}$ & 14.6 \\
\hline Ethephon & 44.7 & 47.8 & 49.3 & 48.2 & 13.5 & 12.8 & 12.6 & $11.2 \mathrm{~d}$ & 15.2 & 16.3 & $10.4 \mathrm{~b}$ & 13.4 \\
\hline AVG1 & 44.5 & 45.9 & 47 & 42.8 & 14.9 & 15.9 & 15.1 & $17.2 \mathrm{a}$ & 13.6 & 12.1 & $15.1 \mathrm{a}$ & 12 \\
\hline AVG2 & 45.5 & 47.1 & 47.2 & 48.3 & 15.9 & 15.4 & 14.4 & $15.0 \mathrm{abc}$ & 14.8 & 15.3 & $15.1 \mathrm{a}$ & 15.6 \\
\hline Untreated & 45.3 & 46.4 & 46.7 & 50.7 & 15.8 & 14.2 & 15.5 & $14.9 \mathrm{bc}$ & 14.9 & 14.7 & $15.3 \mathrm{a}$ & 14.3 \\
\hline
\end{tabular}

${ }^{\mathrm{z}}$ Levels of the monounsaturated fatty acids palmitoleic acid (16:1) and oleic acid (18:1), and the polyunsaturated fatty acids linoleic acid (18:2) and $\alpha$-linolenic acid (18:3).

${ }^{\mathrm{y}}$ Within each column for each fatty acid, means followed by the same letter are not significantly different $(P \leq 0.05)$. Fisher's protected least significant difference test at a $0.05 P$ level was used to detect the difference between treatment means. Columns with no letters indicate no significant differences among chemical treatments.

${ }^{\mathrm{x}}$ Chemical treatments of aminocyclopropane-1-carboxylic acid (ACC), $33.9 \mathrm{~g} \cdot \mathrm{ha}^{-1}$ aminoethoxyvinylglycine (AVG1), and $2.915 \mathrm{~g} \cdot \mathrm{ha}{ }^{-1} \mathrm{AVG}$ (AVG2).

tolerance, as it was found to be differential in bermudagrass cultivars differing in cold tolerance (Cyril et al., 2002). Here, for annual bluegrass, ethephon-treated plants had greater saturated fatty acid content when compared with the untreated controls. Similar results were found for Chlorella vulgaris in response to ethephon treatment (Kim et al., 2016). Harber and Fuchigami (1989) and Lyons and Pratt (1964) discuss findings indicating that increased ethylene levels resulted in greater levels of fatty acid unsaturation. Further testing of ethephon under ice conditions in the field may be warranted to determine whether there are any changes in winter sensitivity following fall applications of ethephon. Additionally, more research on how ethylene is associated with fatty acid changes, perhaps fatty acid desaturase enzyme activity, in grass species under stress conditions is needed.

Ethylene inhibition improved turfgrass recovery from simulated winter conditions (Laskowski and Merewitz, 2020). Ethylene inhibition treatment caused changes in fatty acid content, as some increases in unsaturated fatty acid concentrations and some saturated fatty acids decreases were detected. AVG1-treated annual bluegrass had greater linolenic concentrations when compared with the untreated controls after $80 \mathrm{~d}$ of ice or no ice conditions. Alterations in linolenic acid may not always be required for cold tolerance (Roche, 1979), but it does seem to play an important role in some grass species' responses to cold (Cyril et al., 2002). Compared with fruit tissue, more research is needed on leaf, crown, and root tissue responses in fatty acid changes due to ethylene inhibition treatments and how the treatments may promote abiotic stress tolerance.

In addition to fatty acid changes, ethylene inhibition treatments of annual bluegrass caused greater protein content of the apoplast in leaf tissues compared with controls. Plants have several defenses against cellular ice formation, such as the movement of water from intracellular to inter- or extracellular (apoplastic) areas to reduce the formation of intracellular ice crystals (Atıcı and Nalbantoğlu, 1999). Proteins, some possessing antifreeze activity, may accumulate in the apoplast, which would further reduce ice crystal formation. Some proteins provide antifreeze activity by binding to the surface of ice crystals and thus reducing the rate at which ice may grow in plant tissues (Griffith et al., 1992). Our results are contrary to what researchers have found in winter rye (Secale cereale) leaves, where ethylene promoted apoplastic protein content and ethylene inhibitory treatments had lower apoplastic protein 
concentrations (Yu et al., 2001). We did not find any major, consistent differences in apoplastic protein content due to ethylene regulatory treatments for crown tissues, which is a primary overwintering structure for perennial turfgrasses. Other than species difference, it is unclear why our results contrast with the results in wheat (Triticum aestivum), but further investigation into apoplastic survival mechanisms, or lack thereof, of annual bluegrass may be warranted.

Winter-preparatory treatments using ethylene regulation is novel to this study for the purposes of promoting tolerance to ice encasement and low temperatures. This type of fall plant growth-regulator treatment is being investigated for other purposes, such as reducing unwanted flowering and seed heads in annual bluegrass in the spring, particularly in southern regions of the United States (Askew, 2017). Based on our results and depending on the rate used, fall applications of ethephon to reduce annual bluegrass flowering could be detrimental to annual bluegrass percent regrowth in colder regions (Laskowski and Merewitz, 2020). This current study shows that the percent regrowth reductions could be related to decreased antioxidant activity, increased lipid peroxidation, and higher levels of saturated fatty acids found here in ethephon-treated annual bluegrass.

In conclusion, ethephon treatment of annual bluegrass may be detrimental to spring recovery by increasing lipid peroxidation, increasing saturated fatty acid content, and decreasing antioxidant activity when compared with untreated annual bluegrass after winter conditions. Products that are ethylene inhibitors could potentially be beneficial to annual bluegrass survival during the winter and may act via increases in antioxidant activity and increases in plant cell membrane unsaturated fatty acid contents when compared with untreated annual bluegrass. To use ethylene inhibition as a turfgrass winterpreparatory management strategy, more research into application timing and frequency may be desirable. As simulated winter conditions were used here, testing these treatments in the field may be important future research.

\section{Literature Cited}

Askew, S. 2017. Plant growth regulators applied in winter improve annual bluegrass (Poa annua) seedhead suppression on golf greens. Weed Technol. 31:701-713, doi: 10.1017/wet.2017.73.

Atıc1, Ö. and B. Nalbantoğlu. 1999. Effect of apoplastic proteins on freezing tolerance in leaves. Phytochemistry 50:755-761, doi: 10.1016/S0031-9422(98)00533-0.

Beard, J.B. 1964. Effects of ice, snow and water covers on kentucky bluegrass, annual bluegrass and creeping bentgrass. Crop Sci. 4:638640, doi: 10.2135/cropsci1964.0011183X000400060026x.

Biro, R.L. and M.J. Jaffe. 1984. Thigmomorphogenesis: Ethylene evolution and its role in the changes observed in mechanically perturbed bean plants. Physiol. Plant. 62:289-296, doi: 10.1034/ j.1399-3054.1999.105405.x.

Blokhina, O.B., T.K. Chirkova, and K.V. Fagerstedt. 2001. Anoxic stress leads to hydrogen peroxide formation in plant cells. J. Expt. Bot. 52:1179-1190, doi: 10.1093/jexbot/52.359.1179.

Blokhina, O.B., K.V. Fagerstedt, and T.K. Chirkova. 1999. Relationships between lipid peroxidation and anoxia tolerance in a range of species during post-anoxic reaeration. Physiol. Plant. 105:625-632, doi: 10.1034/j.1399-3054.1999.105405.x.

Bradford, M.M. 1976. A rapid and sensitive method for the quantitation of microgram quantities of protein utilizing the principle of protein-dye binding. Anal. Biochem. 72:248-254, doi: 10.1016/ 0003-2697(76)90527-3.
Chance, B. and A.C. Maehly. 1955. Assay of catalase and peroxidase. Methods Enzymol. 2:764-775, doi: 10.1016/S0076-6879(55)02300-8. Cyril, J., G.L. Powell, R.R. Duncan, and W.V. Baird. 2002. Changes in membrane polar lipid fatty acids of seashore paspalum in response to low temperature exposure. Crop Sci. 42:2031-2037, doi: 10.2135/ cropsci2002.2031.

Dalmannsdottir, S., A. Helgadottir, and B. Gudleifsson. 2001. Fatty acid and sugar content in white clover in relation to frost tolerance and ice-encasement tolerance. Ann. Bot. 88:753-759, doi: 10.1093/ annbot/88.suppl_1.753.

Dhindsa, R., P. Plumb-Dhindsa, and T.A. Thorpe. 1981. Leaf senescence: Correlated with increased levels of membrane permeability and lipid peroxidation, and decreased levels of superoxide dismutase and catalase. J. Expt. Bot. 32:93-101, doi: 10.1093/jxb/32.1.93.

Fukao, T., K. Xu, P.C. Ronald, and J. Bailey-Serres. 2006. A variable cluster of ethylene response factor-like genes regulates metabolic and developmental acclimation responses to submergence in rice. Plant Cell 18:2021-2034, doi: 10.1105/tpc.106.043000.

Giannopolitis, C.N. and S.K. Ries. 1977. Purification and quantitative relationship with water-soluble protein in seedlings. Plant Physiol. 59:315-318, doi: 10.1104/pp.59.2.315.

Griffith, M., P. Ala, D.S.C. Yang, W.C. Hon, and B.A. Moffat. 1992. Antifreeze protein produced endogenously in winter rye leaves. Plant Physiol. 100:593-596, doi: 10.1104/pp.100.2.593.

Harber, R.M. and L.H. Fuchigami. 1989. Ethylene-induced stress resistance. In: P.H. Li (ed.). Low temperature stress physiology in crops. CRC Press, Boca Raton, FL.

Heath, R.L. and L. Packer. 1968. Photoperoxidation in isolated chloroplasts. I. Kinetics and stoichiometry of fatty acid peroxidation. Arch. Biochem. Biophys. 125:189-198, doi: 10.1016/0003-9861(68) 90654-1.

Heatherington, P.R., B.D. McKersie, and A. Morochov. 1987. Ice encasement injury to microsomal membranes from winter wheat crowns. Plant Physiol. 85:1068-1072.

Hon, W.C., M. Griffith, P. Chong, and D.C.S. Yang. 1994. Extraction and isolation of antifreeze proteins from winter rye (Secale cereal L.) leaves. Plant Physiol. 104:971-980, doi: 10.1104/pp.104.3.971.

Kim, S.H., S.R. Lim, S.J. Hong, B.K. Cho, H. Lee, C.G. Lee, and H.K. Choi. 2016. Effect of ethephon as an ethylene-releasing compound on the metabolic profile of Chlorella vulgaris. J. Agr. Food Chem. 64:4807-4816, doi: 10.1021/acs.jafc.6b00541.

Laskowski, K., K. Frank, and E. Merewitz. 2019. Chemical plant protectants and plant growth regulator effects on annual bluegrass survival of ice cover. J. Agron. Crop Sci. 205:202-212, doi: 10.1111/ jac. 12309.

Laskowski, K. and E. Merewitz. 2020. Ethylene regulatory treatment effects on annual bluegrass survival of low temperature and ice cover. Agron. J. 112:861-870, doi: 10.1002/agj2.20030.

Lund, S.T., R.E. Stall, and H.J. Klee. 1998. Ethylene regulates the susceptible response to pathogen infection in tomato. Plant Cell 10:371-382, doi: 10.1105/tpc.10.3.371.

Lyons, J.M. and H.K. Pratt. 1964. An effect of ethylene on swelling of isolated mitochondria. Arch. Biochem. Biophys. 104:318-324, doi: 10.1016/S0003-9861(64)80020-5.

Munshaw, G.C., E.H. Ervin, J.S. Beasley, C. Shang, C. Zhang, and D.J. Parrish. 2010. Effects of late-season ethephon applications on cold tolerance parameters of four bermudagrass cultivars. Crop Sci. 50:1022-1029, doi: 10.2135/cropsci2008.09.0565.

Mutlu, S., Ö. Karadağoğlu, Ö. Atici, and B. Nalbantoğlu. 2013. Protective role of salicylic acid applied before cold stress on antioxidative system and protein patterns in barley apoplast. Biol. Plant. 57:507-513, doi: 10.1007/s10535-013-0322-4.

Nakano, Y. and K. Asada. 1981. Hydrogen peroxide is scavenged by ascorbate-specific peroxidase in spinach chloroplasts. Plant Cell Physiol. 22:867-880, doi: 10.1093/oxfordjournals.pcp.a076232.

Ogren, E. 2000. Maintenance respiration correlates with sugar but not nitrogen concentration in dormant plants. Physiol. Plant. 108:295299, doi: 10.1034/j.1399-3054.2000.108003295.x. 
Okuda, T., Y. Matsuda, A. Yamanaka, and S. Sagisaka. 1991. Abrupt increase in the level of hydrogen peroxide in leaves of winter wheat is caused by cold treatment. Plant Physiol. 97:1265-1267, doi: 10.1104/pp.97.3.1265.

Roche, A.I. 1979. Increase in linolenic acid is not a prerequisite for development of freezing tolerance in wheat. Plant Physiol. 63:5-8, doi: 10.1104/pp.63.1.5.

Samala, S., J. Yan, and W.V. Baird. 1998. Changes in polar lipid fatty acid composition during cold acclimation in 'Midiron' and ' $U 3$ ' bermudagrass. Crop Sci. 38:188-195, doi: 10.2135/cropsci1998. 0011183X003800010031x.

Shang, C., X. Zhang, G. Munshaw, and E. Ervin. 2006. Determination of fatty acid composition of turfgrass by high-performance liquid chromatography. Commun. Soil Sci. Plant Anal. 37:53-61, doi: $10.1080 / 00103620500408605$.

Shi, Y., S. Tian, L. Hou, X. Huang, X. Zhang, H. Guo, and S. Yang. 2012. Ethylene signaling negatively regulates freezing tolerance by repressing expression of CBF and type-A ARR genes in Arabidopsis. Plant Cell 24:2578-2595, doi: 10.1105/tpc.112.098640.

Szalai, G., I. Tari, T. Janda, A. Pestenacz, and E. Páldi. 2000. Effects of cold acclimation and salicylic acid on changes in ACC and MACC contents in maize during chilling. Biol. Plant. 43:637-640, doi: 10.1023/A:1002824721597.

Taşgın, E., O. Atıcı, B. Nalbantoğlu, and L.P. Popovac. 2006. Effects of salicylic acid and cold treatments on protein levels and on the activities of antioxidant enzymes in the apoplast of winter wheat leaves. Phytochemistry 67:710-715, doi: 10.1016/j.phytochem.2006.01.022.

Thomashow, M.F. 1999. Plant cold acclimation: Freezing tolerance genes and regulatory mechanisms. Annu. Rev. Plant Physiol. Plant Mol. Biol. 50:571-599, doi: 10.1146/annurev.arplant.50.1.571.

Tompkins, D.K., J.B. Ross, and D.L. Moroz. 2004. Effects of ice cover on annual bluegrass and creeping bentgrass putting greens. Crop Sci. 44:2175-2179, doi: 10.2135/cropsci2004.2175.

Vargas, J.M. and A.J. Turgeon. 2004. Poa annua: Physiology, culture, and control of annual bluegrass. Wiley, Hoboken, NJ.

$\mathrm{Yu}$, X.M., M. Griffith, and S.B. Wiseman. 2001. Ethylene induces antifreeze activity in winter rye leaves. Plant Physiol. 126:12321240, doi: 10.1104/pp.126.3.1232.

Zhao, M., W. Liu, X. Xia, T. Wang, and W.H. Zhang. 2014. Cold acclimation-induced freezing tolerance of Medicago truncatula seedlings is negatively regulated by ethylene. Physiol. Plant. 152:115-129, doi: 10.1111/ppl.12161. 